\title{
Urease activity according to the different inhibitors
}

\author{
MATEUS P. GOMES ${ }^{1}$, EVERALDO ZONTA ${ }^{2}$, JULIANO B. STAFANATO ${ }^{2}$ and ARIANA M. PEREIRA ${ }^{3}$ \\ ${ }^{1}$ Departamento de Solos, Universidade Federal de Viçosa, Avenida Peter Henry \\ Rolfs, s/n, Campus Universitário, 36570-900 Viçosa, MG, Brazil \\ ${ }^{2}$ Departamento de Solos, Universidade Federal Rural do Rio de Janeiro, BR 465, \\ Km 7, Campus Universitário, 23897-000 Seropédica, RJ, Brazil \\ ${ }^{3}$ Departamento de Fitotecnia, Universidade Federal de Viçosa, Avenida Peter Henry \\ Rolfs, s/n, Campus Universitário, 36570-900 Viçosa, MG, Brazil
}

Manuscript received on August 21, 2017; accepted for publication on May 24, 2018

\begin{abstract}
The objective of this study was to evaluate NBPT, zeolite and humic acid in different concentrations as inhibitors of the activity of the enzyme urease. The activity of the urease enzyme was quantified by the methods proposed by May and Douglas (1976) and Witte and Medina-Escobar (2001). For this reason, two experiments were conducted in a completely randomized design in split plots, in which the incubation periods are the plots and the fertilizers with the inhibitors at the different concentrations are the subplots with three replications. Fifteen fertilizers based on NBPT-coated urea, humic acid and zeolite were used in different concentrations. The two methods of analysis used in the experiment confirmed the efficiency of NBPT in inhibiting the enzymatic action even at low concentration, with $0.02 \%(\mathrm{~m} / \mathrm{m})$ being sufficient to inhibit urease, with no difference between inhibitor concentrations. The addition of humic acid reduced the activity of urease after 36 hours of reaction when the activity of the enzyme was evaluated by the method proposed by May and Douglas (1976). Zeolite did not influence the activity of the urease enzyme when analyzed by the May and Douglas method (1976).
\end{abstract}

Key words: humic acid, nbpt, zeolite, urea.

\section{INTRODUCTION}

Urea is the most commonly used nitrogen fertilizer in agriculture, despite its reduced efficiency particularly due to losses by volatilization of ammonia, which reduce the utilization of the applied nitrogen. For the conversion of $\mathrm{N}$ into the ammoniacal form, urea must be hydrolyzed by the enzyme urease, which is found in almost all types

Correspondence to: Mateus de Paula Gomes

E-mail: mateusgomes2006@yahoo.com.br of soil, in concentrations that range according to the type of the soil and organic matter content, among other soil and climatic characteristics. In addition, factors that influence the microbiological activity of the soil also influence the urease activity and, consequently, the volatilization rates of ammonia.

Researchers and the fertilizer industry have focused their efforts to reduce the losses of nitrogen applied via urea in order to raise the sustainability of nitrogen fertilization. In this sense, several studies have evaluated the reduction of 
ammonia volatilization by adding urease inhibitor compounds. The addition of micronutrients, especially copper and boron, acidifying products and polymers that interfere in the solubilization and/ or hydrolysis of urea are the objective of several studies, but the treatment of urea with NBPT (N-(nbutyl) thiophosphate triamide) inhibitor stood out in the scientific community due to the achievement of good results.

Moreover, the volatilization of ammonia is reduced as CEC (cation-exchange capacity) of the soil increases, the mixture of urea with high CEC products (Monte and Resende 2005), such as zeolites and humic acids, has been evaluated, with the achievement of few promising results (Reháková et al. 2004, Bernardi et al. 2007, Paiva 2009, Yusuff et al. 2009, Bautista et al. 2011). Because of that, further studies are needed especially on the concentration to be used.

As a result, the objective of this study was to evaluate NBPT, zeolite and humic acid in different concentrations, as inhibitors of urease enzyme activity, by means of the methods of May and Douglas (1976) and Witte and Medina-Escobar (2001).

\section{MATERIALS AND METHODS}

The study was conducted at the Soil-Plant Interaction Laboratory (LSP) in the Department of Soils at the UFRRJ Institute of Agronomy, where the activity of the urease enzyme was quantified using the methods proposed by May and Douglas (1976) and Witte and Medina-Escobar (2001).

The experiments were conducted in a completely randomized design in subdivided plots, where the incubation periods are the plots and fertilizers with inhibitors at different concentrations were the subplots with three replications.

In the experiment conducted by using the method proposed by May and Douglas (1976) the treatments consisted of 15 fertilizers, described in Table I.

In the experiment that was carried out using the method proposed by Witte and Medina-Escobar (2001), the treatments with zeolite addition were excluded because the previous tests indicated that the zeolite retains the ammonium and the ammonia of the solution, preventing the reaction of color formation, which impairs the analysis.

Humic acid was obtained from peat which was prepared by drying the material in an oven at $40^{\circ} \mathrm{C}$ and passing through a 60 -mesh sieve. Eighty grams of peat placed in a 1-L centrifuge tube, were weighed. Then, $800 \mathrm{~mL}$ of the alkaline potassium hydroxide $(\mathrm{KOH})$ extracting solution was added at a concentration of $0.1 \mathrm{~mol} \mathrm{~L}^{-1}$, determining a mass/ volume $(\mathrm{m} / \mathrm{v})$ ratio of $1: 10$. The material was left for a two-hour rest and then centrifuged. Extraction was performed at room temperature $\left(25-30^{\circ} \mathrm{C}\right)$.

TABLE I

Fertilizers used.

\begin{tabular}{|c|c|}
\hline 1 & commercial pearled urea \\
\hline 2 & $\begin{array}{l}\text { pearled urea coated with } 0.02 \% \text { of NBPT urease } \\
\text { inhibitor }\end{array}$ \\
\hline 3 & $\begin{array}{l}\text { pearled urea coated with } 0.03 \% \text { of NBPT urease } \\
\text { inhibitor }\end{array}$ \\
\hline 4 & $\begin{array}{l}\text { pearled urea coated with } 0.04 \% \text { of NBPT urease } \\
\text { inhibitor }\end{array}$ \\
\hline 5 & $\begin{array}{l}\text { pearled urea coated with } 0.06 \% \text { of NBPT urease } \\
\text { inhibitor }\end{array}$ \\
\hline 6 & $\begin{array}{l}\text { pearled urea coated with } 0.08 \% \text { of NBPT urease } \\
\text { inhibitor }\end{array}$ \\
\hline 7 & granulated urea with $5 \%$ of humic acid \\
\hline 8 & granulated urea with $10 \%$ of humic acid \\
\hline 9 & granulated urea with $20 \%$ of humic acid \\
\hline 10 & granulated urea with $5 \%$ of zeolite \\
\hline 11 & granulated urea with $10 \%$ of zeolite \\
\hline 12 & granulated urea with $20 \%$ of zeolite \\
\hline 13 & $\begin{array}{l}\text { granulated urea with } 5 \% \text { of humic acid and } 15 \% \text { of } \\
\text { zeolite }\end{array}$ \\
\hline 14 & $\begin{array}{l}\text { granulated urea with } 15 \% \text { of humic acid and } 5 \% \text { of } \\
\text { zeolite }\end{array}$ \\
\hline 15 & $\begin{array}{l}\text { granulated urea with } 10 \% \text { of humic acid and } 10 \% \text { of } \\
\text { zeolite }\end{array}$ \\
\hline
\end{tabular}


The fertilizer granulation process was performed using a 40-cm diameter disk granulator.

Initially, the materials used in the formulation of the fertilizers were milled and sieved in a 1-mm mesh sieve, to allow better homogeneity of the final mixture and to facilitate the granulation to obtain regular granules. Mixtures were prepared using urea milled with the different concentrations of the humic acid and or zeolite. Physical mixtures were carried out using sieves, in order to facilitate the homogenization of the solid components. Liquid ingredients were sprayed onto the solid ingredient previously added to the granulator during the granulation process. The fertilizer was removed from the dish and then sifted and classified as to the size of the granules, if it was between 2 and $4 \mathrm{~mm}$ it was dried at $45^{\circ} \mathrm{C}$ in a forced circulation oven. Fertilizers coated with NBPT at different concentrations were supplied by PETROBRAS.

\section{ANALYSIS METHOD PROPOSED BY MAY AND DOUGLAS (1976)}

For the execution of analysis by using the method proposed by May and Douglas (1976), samples from the 0-20 cm depth of a Red-Yellow Argisol were collected in a pasture area of Empresa de Pesquisa Agropecuária do Estado do Rio de Janeiro (Agricultural Research Company of the State of Rio de Janeiro) - PESAGRO located on Km 47 of BR-465, Seropédica, Rio de Janeiro. The soil collected was air-dried, and later it was crushed and sifted in a 1-mm mesh sieve. The chemical analysis, performed according to that proposed by EMBRAPA (1997), presented the following results: $\mathrm{pH}=5.1 ; \mathrm{Ca}^{2+}=1.2 \mathrm{cmolc} \mathrm{dm}{ }^{-3} ; \mathrm{Mg}^{2+}=1.6 \mathrm{cmolc}$ $\mathrm{dm}^{-3} ; \mathrm{Al}^{3+}=0.3 \mathrm{cmolc} \mathrm{dm}^{-3} ; \mathrm{Na}^{+}=0.0 \mathrm{cmolc} \mathrm{dm}^{-3}$; $\mathrm{K}^{+}=3.6 \mathrm{cmolc} \mathrm{dm}{ }^{-3} ; \mathrm{H}+\mathrm{Al}=3.4 \mathrm{cmolc} \mathrm{dm}^{-3} ; \mathrm{P}=$ $4.5 \mathrm{mg} \mathrm{dm}^{-3} ; \mathrm{SB}=2.9 \mathrm{cmolc} \mathrm{dm}^{-3} ; \mathrm{T}=6.5 \mathrm{cmolc}$ $\mathrm{dm}^{-3} ; \mathrm{V}=45.1 \% ; \mathrm{C}=15.3 \mathrm{~g} \mathrm{~kg}^{-1}$.

The analyzes were performed by adding $3 \mathrm{~g}$ of air dried soil in 50-mL Erlenmeyer's flasks, then $0.5 \mathrm{~mL}$ of toluene and $12.0 \mathrm{~mL}$ of deionized water were added. Incubation was carried out at $30^{\circ} \mathrm{C}$ for 10 minutes in an oven. After that, $3 \mathrm{~mL}$ of the ureacontaining fertilizer solution at a concentration of $0.1 \mathrm{~mol} \mathrm{~L}^{-1}$ was added, which is equal to $0.2 \mathrm{~mol}$ $\mathrm{L}^{-1}$ of $\mathrm{N}$ for all treatments. The Erlenmeyers were then capped and incubated again at $30^{\circ} \mathrm{C}$ for 2,4 , 6, 24 and 36 hours. After each incubation time, $15 \mathrm{~mL}$ of $2 \mathrm{~mol} \mathrm{~L}^{-1} \mathrm{KCl}$ solution was added with $5 \mathrm{mg}$ of phenylmercury acetate, stirred for five minutes, and then filtered. The determination of the exchangeable $\mathrm{N}$-ammoniacal content was carried out by the steam distillation method (Bremner and Keeney 1965).

A blank was performed for each treatment in the manner described above, however, by adding the fertilizer solution after the solution of $\mathrm{KCl}+$ phenylmercury acetate. From the filtrate, $10 \mathrm{~mL}$ were used for the distillation, then, titrated with standard solution of sulfuric acid in a concentration of approximately $0.0025 \mathrm{~mol} \mathrm{~L}^{-1}$.

\section{ANALYSIS METHODS PROPOSED BY WITTE AND MEDINA-ESCOBAR (2001)}

To perform the analyzes according to the method proposed by Witte and Medina-Escobar (2001), also known as the indophenol method, $7 \mathrm{~g}$ of phenol and $34 \mathrm{mg}$ of sodium nitroprusside were dissolved in $80 \mathrm{~mL}$ of distilled water. The volume was completed up to $100 \mathrm{~mL}$ and the solution was stored at $4{ }^{\circ} \mathrm{C}$, protected from light (solution A). Then, $2.96 \mathrm{~g}$ of $\mathrm{NaOH}$ was dissolved in $140 \mathrm{~mL}$ of distilled water, then $29.74 \mathrm{~g}$ of $\mathrm{Na}_{2} \mathrm{HPO}_{4} \cdot 12 \mathrm{H}_{2} \mathrm{O}$ were added and the solution was stirred until the reagents were completely dissolved. After that, $40 \mathrm{Ml}$ of $\mathrm{NaOCl}(4-6 \%)$ was added. The $\mathrm{pH}$ was adjusted to 12 and the volume completed to 200 $\mathrm{mL}$. The solution was stored at room temperature and protected from light (solution B).

For the preparation of the enzyme solution, 3.6 $\mathrm{mg}$ of Canavalia ensiformis urease (Urease-U1500) purchased from Sigma Chemical Company dissolved in one liter of distilled water was used. 
It was added $520 \mu \mathrm{L}$ of the enzyme solution and $80 \mu \mathrm{L}$ of the solution with the fertilizer containing $1 \mathrm{~mol} \mathrm{~L}^{-1}$ of urea, equivalent to $2 \mathrm{~mol} \mathrm{~L}^{-1}$ of $\mathrm{N}$ in each test tube, then stirred and left in a water bath at $43{ }^{\circ} \mathrm{C}$ during the pre-established reaction intervals. After that, $80 \mu \mathrm{L}$ of the sample was pipetted combined with $3920 \mu \mathrm{L}$ of distilled water, $40 \mu \mathrm{L}$ of the reagent $\mathrm{A}$ and $400 \mu \mathrm{L}$ of reagent $\mathrm{B}$. The tubes were capped immediately after addition of reagent $\mathrm{B}$ to prevent loss of ammonia. The tubes were then shaken and left in a water bath at $50^{\circ} \mathrm{C}$ for 20 minutes so the solution would develop color. At the end of the water bath, the tubes remained for an hour and a half at room temperature, so that the solutions stabilized.

For the construction of the calibration curve, $200 \mu \mathrm{L}$ of ammonium chloride solution at concentrations of $0,25,50,100,200$ and $400 \mu \mathrm{mol}$ $\mathrm{L}^{-1}$ were mixed with $800 \mu \mathrm{L}$ of water, which were submited to step 2. Ammonium was determined from the spectrophotometer absorbance readings by using the wavelength of $636 \mathrm{~nm}$.

The results were submitted to the F test and the means compared by the Scott-Knott test at 5\% of significance.

\section{RESULTS AND DISCUSSION}

RESULTS ACHIEVED BY THE MAY AND DOUGLAS METHOD (1976)

The fertilizers added with NBPT resulted in low values of ammonium in solution and after two hours of incubation (Figure 1), the compound had already exerted an inhibitory action upon the enzyme.

The efficiency of NBPT depends on the conversion rate to its oxygen analogue (NBPTO). The details of this reaction are still not known, however, some authors state that the conversion reaction of NBPT to NBPTO is slow or it does not occur in anaerobic environments (Keerthisinghe and Freney 1994, Watson et al. 2008). Pro et al. (2014) suggest that the replacement of sulfur by oxygen in the conversion of the compounds only occurs in the soil and probably due to the action of bacteria.

In this study, fertilizers additivited with NBPT were incubated in solution together with the soil. Even in the anaerobic environment and at the lowest dose $(0.02 \%)$, the compound proved to be efficient in inhibiting the hydrolytic activity of urease. Commercial formulations generally use concentrations ranging from 500 to $2000 \mathrm{mg}$ NBPT $\mathrm{kg}^{-1}$ urea (0.05 to $0.2 \%$ ), although the dose used in Brazil is about $530 \mathrm{mg} \mathrm{kg}^{-1}(0.053 \%)$ (Cantarella and Marcelino 2007).

Keerthisinghe and Blakeley (1995) reported a 48\% lower hydrolysis for urea treated with $100 \mu \mathrm{mol} \mathrm{L}{ }^{-1}$ of NBPT, when compared to urea without the compound, incubated for 30 minutes. By reducing the incubation time to $10 \mathrm{~min}$ and the concentration of NBPT to $50 \mu \mathrm{mol} \mathrm{L}{ }^{-1}$, a reduction of $22 \%$ was found in urea hydrolysis. The authors considered that the incubation periods were short for the conversion of NBPT to NBPTO and attributed this inhibition to the presence of NBPTO as an impurity present in the NBPT added to urea.

No difference was found in the inhibition rate between compound concentrations at any of the incubation periods (Figure 1). It is recommended to increase the dose of NBPT in situations where urease is present at high concentrations and in conditions that promote it such as at elevated $\mathrm{pH}$ and temperature (Bremner and Chai 1986, Schlegel et al. 1986, Carmona et al. 1990, Watson et al. 1994).

It is likely that the amount of soil added for the analyzes provided a low concentration of the enzyme, so the lower NBPT concentration was sufficient to reduce the hydrolysis of the urea. Treatments with urea treated with $0.08 \%$ NBPT showed enzymatic activity $61 \%$ lower than the common urea treatment. After 2 hours of incubation, this treatment reached urease activity $72 \%$ lower than the control, after 36 hours.

The zeolite-added urea treatments and the treatments with zeolite and humic acid mixture $(5 \%$ 
a.

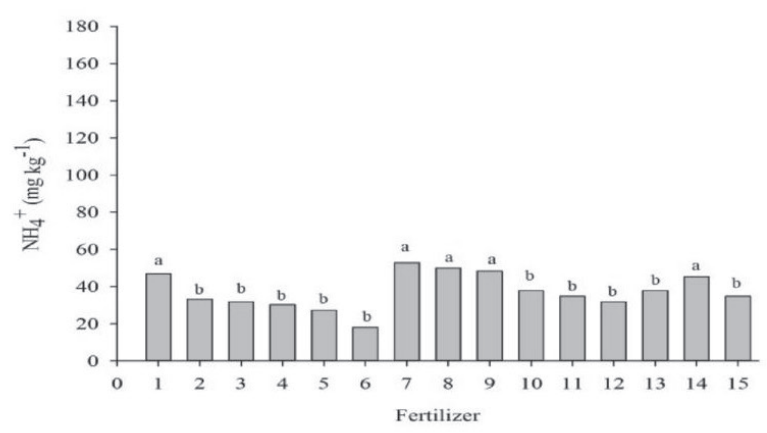

c.

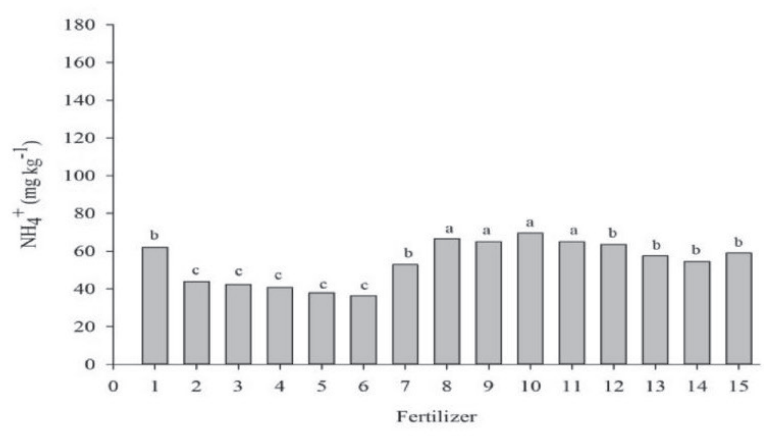

b.

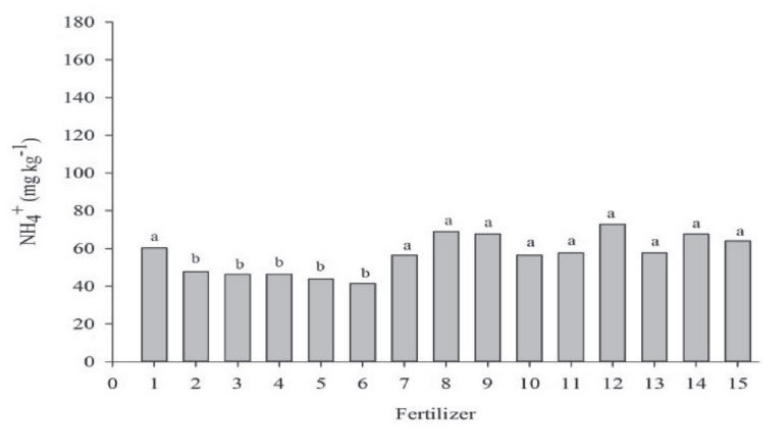

d.

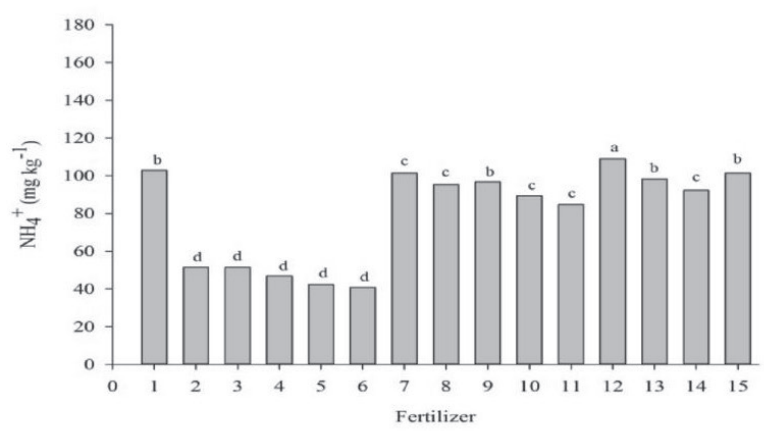

e.

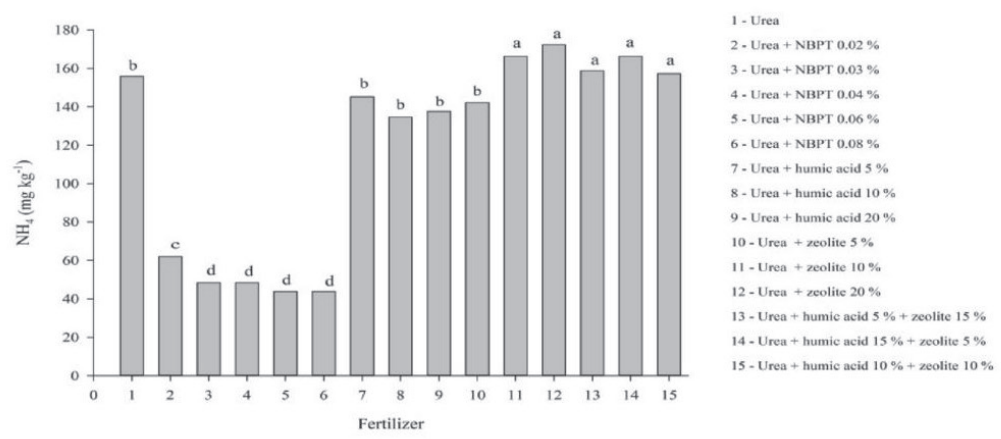

Figure 1 - Ammonium production, due to the hydrolysis of the conventional and additive urea, submitted to (a.) - 2, (b.) - 4, (c.) - 6, (d.) - 24 and (e.) - 36 hours of incubation. Different letters between the columns indicate difference by the Scott-Knott test at 5\%. Analyzes carried out following proposed methodology May and Douglas (1976).

humic acid, 15\% zeolite, 10\% humic acid, 10\% zeolite) differed from the control (conventional urea) in the two-hour incubation. A difference was found between the treatment of urea with $5 \%$ zeolite and the control after 36 hours. These results are probably the response of the low ammonium extraction time with the $\mathrm{KCl}$ solution, where part of the $\mathrm{N}^{-\mathrm{NH}_{4}}{ }^{+}$ may have remained adsorbed to the mineral.

The competitive enzymatic inhibition for a compound is due to the similarity in its chemical structure with the enzymatic substrate, which allows its interaction with the active center of 
a.

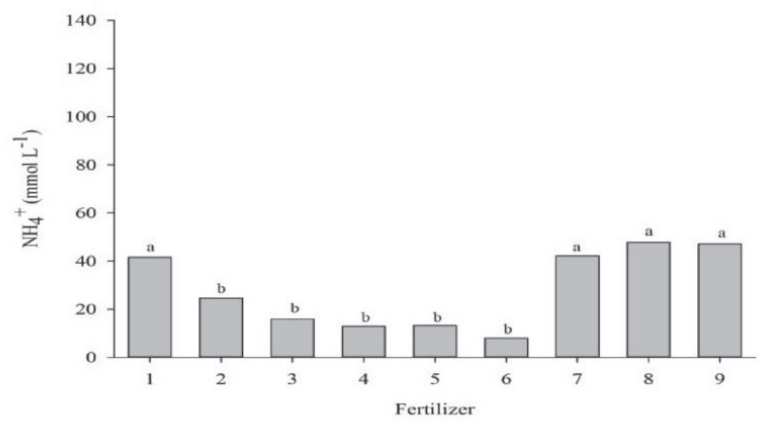

c.

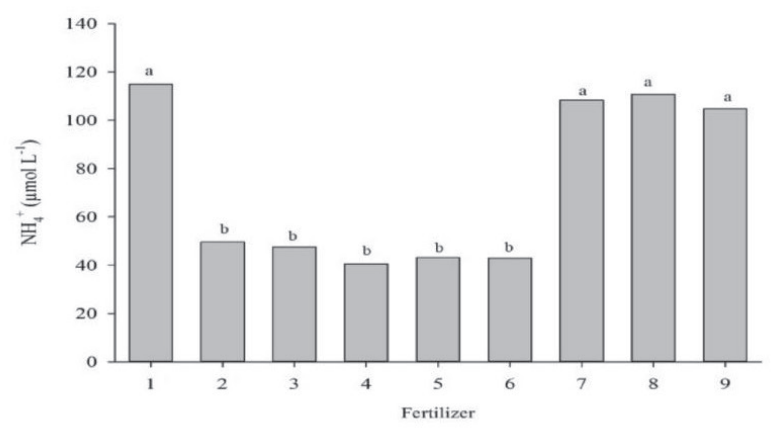

b.

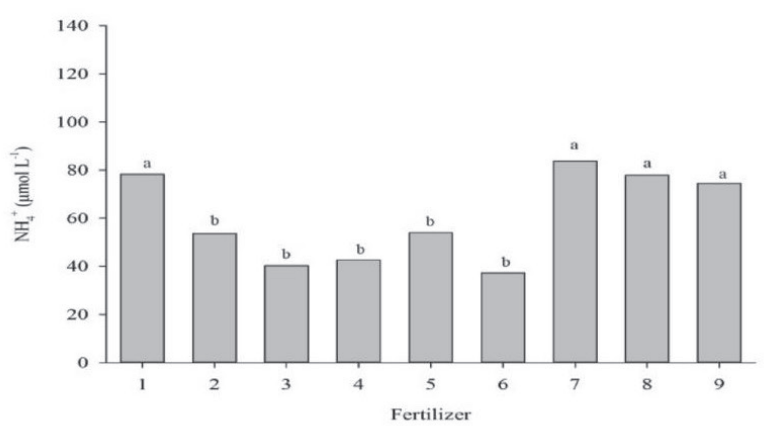

d.

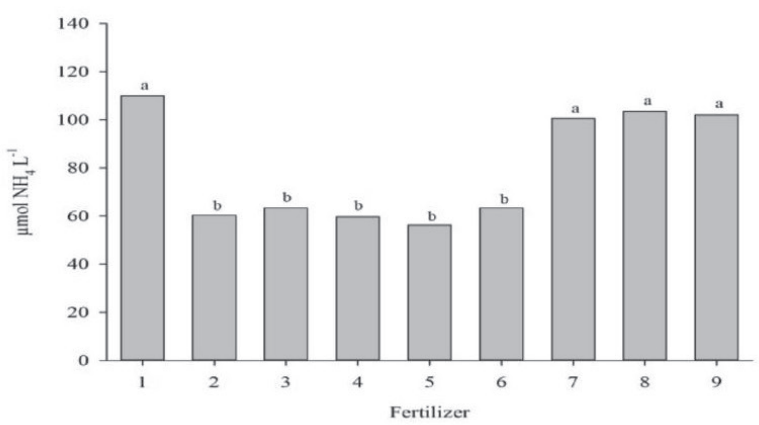

e.

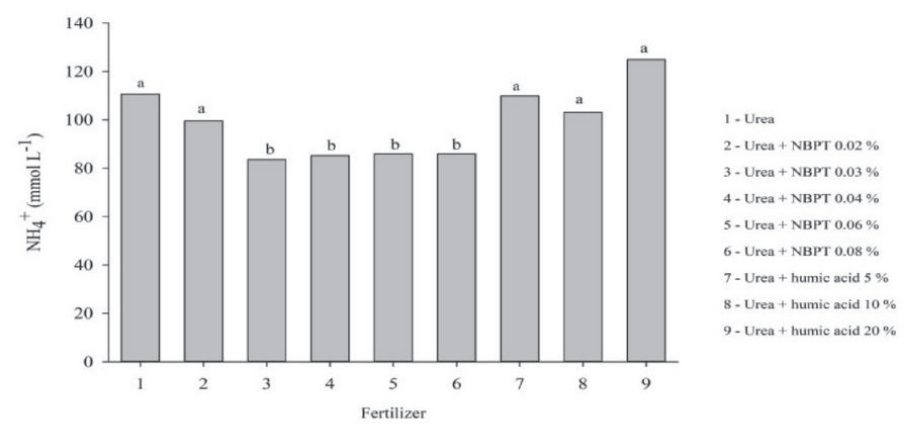

Figure 2 - Ammonium production, due to the hydrolysis of the conventional and additive urea, submitted to (a.) - 2, (b.) - 4, (c.) - 6, (d.) - 24 and (e.) - 36 hours of incubation. Different letters between the columns indicate difference by the Scott-Knott test at 5\%. Analyzes carried out following proposed methodology Witte and Medina-Escobar (2001).

the enzyme (Paiva 2009). Zeolites do not present structural similarity to urea and therefore they are not expected to exert competition for the active site of the enzyme.

The treatments with humic acid differed from the control treatment, with a reduction of up to $14 \%$ of the enzymatic activity for the treatment with $10 \%$ of humic acid, but the different concentrations of humic acid did not differ among each other. Probably, the effect of the humic acids on the enzymatic activity is due to the reduction of the $\mathrm{pH}$ of the reaction solution, since it was observed that the addition of humic acid to the urea reduced the initial $\mathrm{pH}$ of the reaction solutions (unpublished data). Longo and Melo (2005) observed that the enzymatic activity remained 42 to $44 \%$ below the 
maximum activity of the enzyme at $\mathrm{pH} 5.2$ and the maximum activity was recorded at $\mathrm{pH} 8$.

\section{RESULTS OBTAINED FROM THE WITTE AND} MEDINA-ESCOBAR METHOD (2001)

The results obtained by using this method (Figure 2) were similar to the results obtained by the method proposed by May and Douglas (1976), in which the NBPT was effective after the first incubation period, but did not differ between the concentrations of the compound.

It is observed that after 36 hours of incubation, the efficiency of the inhibitor was considerably reduced (Figure 2). In this case, it is possible that the greatest contribution to the reduction of inhibitor efficiency was due to the incubation temperature $\left(43^{\circ} \mathrm{C}\right)$. The increase in temperature promotes urease activity (Longo and Melo 2005, Zantua and Bremner 1977), however, it was expected that higher concentrations of NBPT would maintain inhibition of hydrolysis, which was not observed. In this case, the incubation time may have been not sufficient for conversion of the NBPT to the NBPTO, since the reaction is slow in solution.

The maximum inhibition observed occurred in the shortest incubation period (two hours), and the enzymatic activity in treatment with urea treated with $0.08 \%$ NBPT was $81 \%$ lower than the enzyme activity in the treatment with common urea. After 36 hours of incubation, the urea treated with the lowest concentration of NBPT $(0.02 \%)$ was already equal to the common urea, showing the reduction of the efficiency of the inhibitor with the increase of the incubation time.

Treatments with urea additivited with humic acid showed no urease activity, differing from the treatment with common urea. In this case, it is possible that the incubation temperature compensated for the reduction of $\mathrm{pH}$ promoted by the humic acid.

\section{ACKNOWLEDGMENTS}

To the Conselho Nacional de Desenvolvimento Científico e Tecnológico (CNPq), the Coordenação de Aperfeiçoamento de Pessoal de Nível Superior (CAPES), and the Universidade Federal Rural do Rio de Janeiro (UFRRJ).

\section{REFERENCES}

BAUTISTA JM, KIM H, AHN DH, ZHANG R AND OH YS. 2011. Changes in physicochemical properties and gaseous emissions of composting swine manure amended with alum and zeolite. Korean J Chem Eng 28: 189-194.

BERNARDI ACC, PAIVA PRP AND MONTE MBM. 2007. Produção de matéria seca e teores de nitrogênio em milho para silagem adubado com ureia misturada a zeólita. Embrapa Pecuária Sudeste, comunicado técnico 77.

BREMNER JM AND CHAI HS. 1986. Evaluation of N-butyl phosphorothioic triamide for retardation of urea hydrolysis in soil. Commun Soil Sci Plant Anal 17: 337-351.

BREMNER JM AND KEENEY DR. 1965. Steam distillation methods for determination of ammonium, nitrate and nitriti. Anal Chim Acta 32: 485-495.

CANTARELLA H AND MARCELINO R. 2007. Uso de inibidor de urease para aumentar a eficiência da ureia. In: Simpósio sobre informações recentes para otimização da produção agrícola, p. 2-19.

CARMONA G, CHRISTIANSON CB AND BYRNES BH. 1990. Temperature and low concentration effects of the urease inhibitor N-(n-butyl)thiophosphoric triamide (nBTPT) on ammonia volatilization from urea. Soil Biol Biochem 22: 933-937.

EMBRAPA - EMPRESA BRASILEIRA DE PESQUISA AGROPECUÁRIA. 1997. Manual de métodos de análises de solo, $2^{\text {a }}$ ed., Rio de Janeiro, Ministério da Agricultura e do Abastecimento, $212 \mathrm{p}$.

KEERTHISINGHE DG AND BLAKELEY RL. 1995. Inhibition of jack bean urease by phosphoric-and thiophosphoric triamides. Soil Biol Biochem 27: 739-742.

KEERTHISINGHE DG AND FRENEY JR. 1994. Inhibition of urease activity in flooded soils: Effect of thiophosphorictriamides and phosphorictriamides. Soil Biol Biochem 26: 1527-1533.

LONGO RM AND MELO WJ. 2005. Hidrólise da ureia em Latossolos: Efeito da concentração de ureia, temperatura, pH, armazenamento e tempo de incubação. Rev Bras Ciênc Solo 29: 651-657.

MAY PB AND DOUGLAS LA. 1976. Assay for soil urease activity. Plant Soil 45: 301-305. 
MONTE MBM AND RESENDE NGAM. 2005. Zeolitas Naturais. In: Lins FF and Luz AB (Eds), Rochas e Minerais Industriais. Cetem, p. 699-720.

PAIVADM. 2009. Redução na volatilização de amônia derivada da ureia por ácidos húmicos produzidos de carvão de eucalipto. Dissertação de Mestrado, Universidade Federal de Viçosa, Viçosa, Minas Gerais, 53 p. (Unpublished).

PRO D, HUGUET S, ARKOUN M, NUGIER-CHAUVIN C, GARCIA-MINA JM, OURRY A, WOLBERT D, YVIN JC AND FERRIÈRES V. 2014. From algal polysaccharides to cyclodextrins to stabilize a urease inhibitor. Carbohydr Polym 112: 145-151.

REHÁKOVÁ M, CUVANOVÁ S, DZIVÁK M, RIMÁR J AND GAVAL'OVÁ Z. 2004. Agricultural and agrochemical uses of natural zeolite of the clinoptilolite type. Curr Opin Solid St M 8: 397-404.

SCHLEGEL AJ, NELSON DW AND SOMMERS L. 1986. E. Field evaluation of urease inhibitors for corn production. Agron J 78: 1007-1012.

WATSON CJ, AKHONZADA NA, HAMILTON JTG AND MATTHEWS DI. 2008. Rate and mode of application of the urease inhibitor $\mathrm{N}$-(n-butyl) thiophosphoric triamide on ammonia volatilization from surface-applied urea. Soil Use Manage 24: 246-253.

WATSON CJ, MILLER H, POLAND P, KILPATRICK DJ, ALLEN MBD, GARRET MK AND CHRISTIANSON CB. 1994. Soil properties and the ability of the urease inhibitor N-(n-butyl) thiophosporic triamide (nBTPT) to reduce ammonia volatilization from surface-applied urea. Soil Biol Biochem 26: 1165-1171.

WITTE CP AND MEDINA-ESCOBAR N. 2001. In-gel detection of urease with nitroblue tetrazolium and quantification of the enzyme from different crop plants using the indophenol reaction. Anal Biochem 290: 102107.

YUSUFF MTM, AHMED OH AND AB MAJID NM. 2009. Effect of Mixing Urea with Humic Acid and Acid Sulphate Soil on Ammonia Loss, Exchangeable Ammonium and Available Nitrate. Am J Environ Sci 5: 588-591.

ZANTUA MI AND BREMNER JM. 1977. Stability of urease in soils. Soil Biol Biochem 9: 135-140. 